\title{
In vitro analysis of the effect of Go Ark on Human Peripheral Blood Lymphocytes
}

\author{
Research Article
}

\section{Daya Shankar Gautam ${ }^{*}$, Prahlad Marskole², Saraswati Mishra², Nisha Tiwari², Anjali Kumari2, Sakshi Dwivedi2, Kahkashan $\mathbf{N a z}^{2}$}

\author{
1. Assistant Professor, 2. MSc Students, Department of Zoology, \\ St Aloysius' College (Autonomous), Jabalpur (M. P.), India.
}

\begin{abstract}
Cow is worshiped in India as "Gomata" since ancient time. Its values have been signified in Vedas, Puranas \& Ayurveda. Its urine/Go Ark is used in rituals \& medicines traditionally in India. The Significance of Cow Urine has been studied by many workers. Now it is available in the market as distillate. Hence this study was designed to assess the potential of Fresh Go Ark (FGA) and Distillate Go Ark (DGA) on Human Peripheral blood lymphocytes (PBL) in Vitro using MTT Assay. It was found that FGA \& DGA both had the potential to enhance the cell viability of Human PBL. FGA showed greater potential towards the enhancement of cell viability on Human PBL than that of DGA. However the difference between the impacts of FGA \& DGA was not found to be significant when tested through Two way ANOVA.
\end{abstract}

Key Words: Fresh Go Ark, Distillate Go Ark, MTT Assay, Cow urine, Cell viability, Human PBL.

\section{Introduction}

Cow in India is worshiped like mother of all living beings which provides all pleasures to them. All the products obtained from cow possess medicinal properties. Cow urine/Go Ark (GA)/ is used as a medicine to cure from many curable and incurable ailments. The significance of GA is mentioned in many Ayurvedic classical texts, such as Sushrut Samhita, Bhavprakash and Charaka Samhita.(1)

GA is supposed to have therapeutic value. It is used in many drug formulations. Essentially, GA is used for purification and also as a disinfectant. It has a shelf life of around 5 years. So it can be the most effective natural antiseptic and disinfectant as compared to the synthetic chemicals which are currently been used for the same purposes by the people. (2)

Bhadauria et al (3) explained that GA is not a toxic substance as it contains $2.5 \%$ urea, $95 \%$ water and $2.5 \%$ a mixture of hormones, salts, minerals and enzymes.

GA is a secretion of animal origin with an effective medicinal \& therapeutic uses. Cow (Kamadhenu) is considered as a holy animal by Indians. In Rigveda (10/15), considers GA as nectar. Numerous medicinal properties of GA are mentioned in Charak (shloka-100) and in Susruta (45/221) such as reversal of certain cardiac and renal diseases, anemia, jaundice,

\section{* Corresponding Author:}

\section{Daya Shankar Gautam}

Assistant Professor, Department of Zoology,

St Aloysius' College (Autonomous),

Jabalpur (M. P.), India

Email Id:dygautam@gmail.com weight loss, indigestion, diarrhea, edema, skin diseases including vitiligo, stomach ache and hemorrhoids. It is capacity to correct all the imbalances in the body and maintains the general health of organisms. (4)

It is believed that GA is gifted by god to the people. Now a day's a number of incurable diseases are occurring in the world harming human societies. GA is solution for all diseases which is used for treating illnesses like skin disorder, blood pressure, constipation, cancer, diabetes, AIDS etc. GA has been used in the rural areas in India since ancient time as an effective antiseptic for skin diseases, wounds, bathing, etc. (5)

Eight types of animals can be used for obtaining urine, out of which GA is believed as the best. Skin-disorders (Kushtha, Pama, Kilasa, Kandu), Gastro Intestinal disorders (Kamala, Pandu, Gulma, Atisara, Krumi, Aanaha, Mutraroga), Kasa, Shwasa and Visha are treated by the use of GA. Oral administration of GA is used to treat diseases. (6)

Nitrogen, phosphate, sulphur, manganese, sodium, iron, chlorine, silicon, magnesium, tartaric and calcium salts, maleic, vitamin A, B, C, D, E, citric, enzymes, creatinine, minerals, lactose, gold acids and hormones are found in GA. GA ingredients resembles with human body. Therefore, consumption of GA is beneficial to retain the equilibrium of these substances. It cures many such diseases which are incurable. (7)

GA is considered the elixir of life in the ancient scriptures of Ayurveda. GA based drug formulations would certainly be proved to have a potential medicine that will diminish the increasing pressure on for the use of antibiotics and chemicals. It has the potential to be used for the management of many diseases. This urine therapy could have a great scope for curing wide range of diseases which are dreadful because it is 
economically viable, eco-friendly and easily available naturally in abundance. (2).

GA distillate has been observed as a 'bioenhancer'/ 'biopotentiator' substances by Randhawa GK (9) which increase bio-efficacy of active substance and bioavailability. In Ayurveda, 'yogvahi' principle to describe the bioenhancing properties of medicines $\mathrm{s}$ described. It increases the oral bioavailability which results in dropping their dose and side effects. More viable drug formulations can be developed by the integration of Ayurvedic science with modern techniques of research.

Rasayana medicine has potential to strengthen body immune system in Ayurveda and the GA holds the similar Rasayana tatva so it serves as bioenhancer. Distillate Go Ark (DGA) has been observed more effective bioenhancer than GA. (10)

The MTT (3-[4,5-dimethylthiazol-2-yl]-2,5 diphenyl tetrazolium bromide) assay is based on the conversion of MTT into formazan crystals by living cells. This assay determines mitochondrial activity. This assay is broadly used to evaluate the in vitro cytotoxic effects of drugs on cell lines or primary patient cells as in most of the cell populations the total mitochondrial activity relates to viable cells percentage. (11)

Therefore, the current research is designed to analyze the effect of Fresh Go Ark (FGA) \& Distilled Go Ark (DGA) in vitro on human PBL using MTT assay.

\section{Materials and Methods Collection of FGA \& DGA}

Midstream FGA was collected in a sterile urine container. It was centrifuged. Supernatant was used as FGA. DGA was purchased from market. It is a product marketed by Gau Vigyan Anusandhan Kendra, Nagpur.

\section{Isolation of lymphocytes from whole blood}

Isolation of lymphocytes was performed as per Gautam DS et al (12) with some modifications. Blood $(2.5 \mathrm{ml})$ from healthy male volunteer donor was collected in sterile EDTA vacutainer. This was diluted with double volume $(5 \mathrm{ml})$ of PBS (1X).

2.5 milliliter of HiSep TM lymphocyte separation medium (LSM) 1077 (Hi media) was transferred aseptically into a centrifuge tube. This was done carefully overlaid with $7.5 \mathrm{ml}$ of diluted blood. It was centrifuged at $3000 \mathrm{rpm}$ at room temperature for 30 minutes. Erythrocytes were sedimented and the lymphocytes formed a layer above the HiSep layer.

Most of the supernatant was aspirated out and then the lymphocyte layer along with half of HiSep layer was carefully aspirated into a separate centrifuge tube. It was then given one wash wish isotonic PBS (1X).

The cells were counted in a haemocytometer. The cells were appropriately diluted in TC 199 medium (Hi media) supplemented with fetal bovine serum to give a final concentration of $3.03 \times 10^{5}$.

\section{MTT ASSAY}

MTT assay was performed according to Mosmann (13) with some modification. Aliquots of $(180 \mu 1)$ of the prepared lymphocytes suspension $\left(3.03 \times 10^{5}\right)$ were seeded into a 96 well polystyrene tissue culture plate in 6 replicates of each sets i.e. SET-1 and SET-2.

- One row (A) containing only medium and cells served as a control. FGA and DGA dilutions were made and were added to cell suspension in the concentrations of $100 \%(\mathrm{~B}), 70 \%(\mathrm{C}), 40 \%(\mathrm{D}), 10 \%(\mathrm{E})$ and $1 \%(\mathrm{~F})$. A-F indicated the rows of microtitre plate to be used for the treatment under SET-1 and SET-2. Each concentration of FGA and DGA $(20 \mu 1)$ was tested on cell suspension in six replicates for SET-1 and SET-2 for 2 hours exposure.

- The absorbance of each concentration of only FGA and DGA was also taken respectively.

- The plate was incubated for 2 hours exposure at $37^{\circ} \mathrm{C}$ at $5 \% \mathrm{CO}_{2}$. After incubation, $20 \mu 1$ aliquots of MTT solution $(5 \mathrm{mg} / \mathrm{ml}$ PBS $)$ were added to each well of SET- 1 and SET-2.

- The plate was re-incubated for 2 hours at $37^{\circ} \mathrm{C}$. Then $100 \mu 1$ of dimethyl sulfoxide (DMSO) was added to each well to dissolve formazan crystals followed by overnight incubation.

- The culture plate was then placed in an Enzyme Linked Immune Sorbent Assay (ELISA) microplate reader and absorbance was read at $600 \mathrm{~nm}$ after 24 hours for SET-1 and SET-2.

- The readings are noted, analyzed by making due adjustment with these data the in vitro effect of FGA and DGA on Human PBL was calculated.

- Cell viability rate was calculated as the $\%$ of formed formazan crystal during experiment as follows: $\begin{aligned} \% \text { survival }= & (\text { Mean experimental absorbance } / \text { Mean } \\ & \text { control absorbance }) \times 100\end{aligned}$

\section{Results}

Table 1: Cell viability \% of FGA and DGA on Human PBL

\begin{tabular}{|c|c|c|}
\hline Treatments & \multicolumn{2}{|c|}{ Cell viability\% } \\
\hline Concentrations of GA & FGA & DGA \\
\hline CTRL & 100.00 & 100.00 \\
\hline $100 \%$ & 163.98 & 83.91 \\
\hline $70 \%$ & 161.53 & 105.45 \\
\hline $40 \%$ & 102.81 & 95.89 \\
\hline $10 \%$ & 93.31 & 92.20 \\
\hline $1 \%$ & 107.00 & 98.72 \\
\hline
\end{tabular}

\section{Effect of FGA on Human PBL}

The cell viability $\%$ on FGA exposed group at $100 \%$ and $1 \%$ was found to be 163.98 and 107 respectively. FGA also showed positive effect with other concentrations $(70 \%, 40 \%$, and $10 \%)$ on cell viability\% as compared to control (ctrl) group (Table 1). The trend showed the concentration of FGA was directly proportional to the cell viability\%. (Figure 2) 


\section{Effect of DGA on Human PBL}

The cell viability\% on DGA exposed group at $100 \%$ and $1 \%$ was found to be 83.91 and 98.72 respectively. DGA also showed positive effect on cell viability $\%$ when treated with other concentrations $(70 \%, 40 \%$, and $10 \%)$ as compared to ctrl group (Table 1). The trend showed the concentration of DGA was directly proportional to the cell viability\%. (Figure 3)
Overall cell viability\% caused by FGA was found to be $121.44 \%$, while due to DGA it was $96.03 \%$ which is very close to ctrl. (Figure 1)

When we compared cell viability\% on human PBL after the exposure of FGA and DGA for $2 \mathrm{hrs}$, we found that FGA enhanced the cell viability $\%$ as compared to DGA (Figure 4). DGA was not found to be toxic while FGA enhanced the viability of Human PBL when treated in vitro. However, the difference was not found to be significant. (Table 2)

Table 2: Two-wayANOVA for analysis of FGA and DGA

\begin{tabular}{|c|c|c|c|c|c|c|}
\hline \multicolumn{7}{|l|}{ ANOVA } \\
\hline Source of 'Variation & SS & df & MS & $\mathbf{F}$ & P-value & F crit \\
\hline Rows & 2596.998 & 5 & 519.3997 & 0.895566 & 0.546694 & 5.050329 \\
\hline Columns & 1937.123 & 1 & 1937.123 & 3.340052 & 0.127163 & 6.607891 \\
\hline Error & 2899.839 & 5 & 579.9678 & & & \\
\hline Total & 7433.96 & 11 & & & & \\
\hline
\end{tabular}

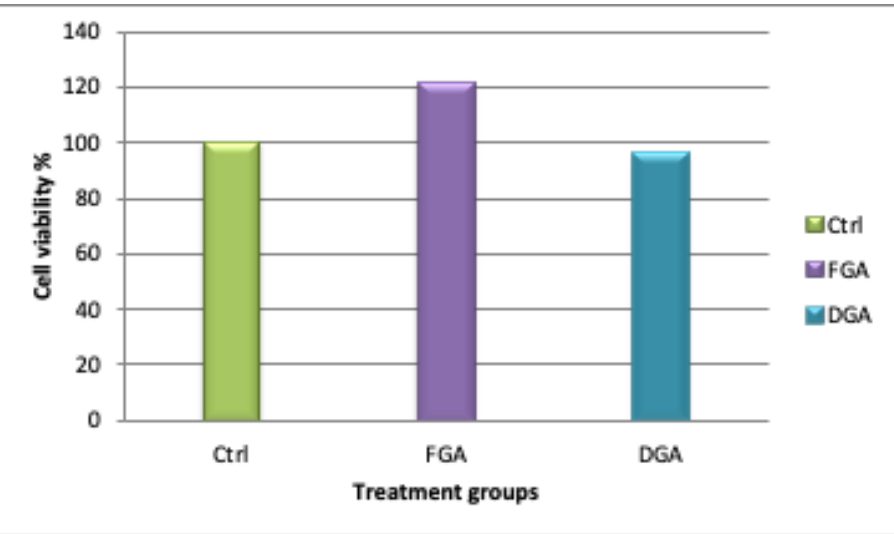

Figure 1: Overall impact of FGA and DGA on Human PBL

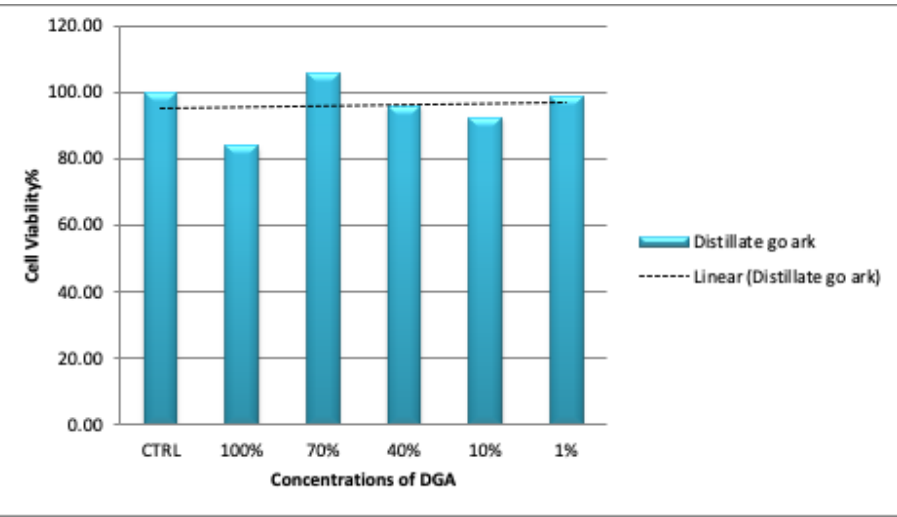

Figure 3: Effect of DGA on Cell Viability

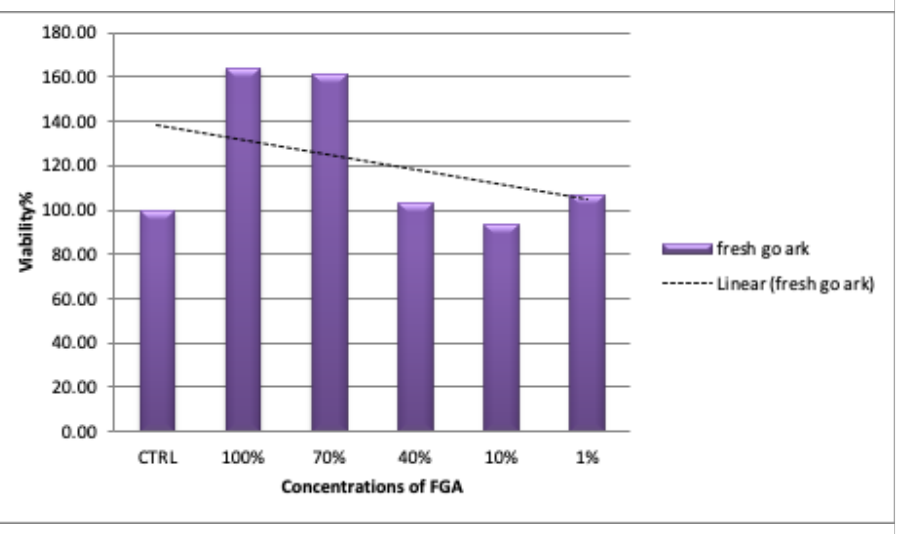

Figure 2: Effect of FGA on Cell Viability \%

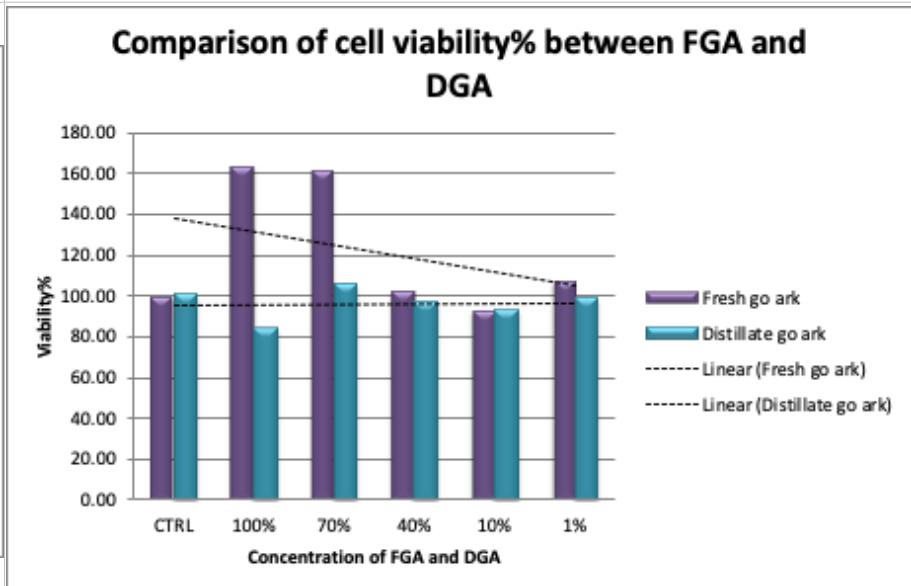

Figure 4: Comparison of cell viability\% between FGA and DGA

\section{Discussion}

Gulhane $\mathrm{H}$ et al (14) after analyzing different results on GA in various research articles observed that GA and its mixture was a multidimensional drug. It has been mentioned in the Ayurveda that FGA of indigenous cow is the most potent to be used as a drug.
Talokar OW et al (15) described that oral supplementation with the GA prevented painful, timeconsuming and expensive difficulties of Hemorrhoids. (15)

Randhawa GK (8) studied, chemotherapeutic potential of cow urine in a review. A significant effect in wound healing activity in Wistar albino rats was found 
by the use of GA. They observed that GA heals wound faster $1 \% \mathrm{w} / \mathrm{w}$ than nitrofurazone ointment locally.

In various Ayurvedic formulations, various properties and activity of GA have been applied and widely used. Lashunadhghrita, Panchagavyaghrita, Sidhartakghrita are used for abdominal tumor and psychiatric illness. The formulations of drugs like Darvighrita, Mandurvatak and Punnarvamandur contain GA which is an adjuvant along with Swarnmakshikbhasma' Hareetakyadiyog, Gvakshyadichurana, Swarnkshiryadyog. The Bhasms, Yogs, and Churans are available in the powder form and Ghritas (Medicated cow Ghee) are also available as semisolid substance. The guiding principal of Ayurveda is the use of herbs and minerals (like Panchgavya and Chavanpras) for improving the overall resistance of the body against common infections and pathogens. Ancient Ayurvedic treatises described that daily consumption of GA increases the resistance to diseases by up to $104 \%$. Mice have also been experimented to show the enhancement in humoral and cell-mediated immune response. (4)

Dhama K. et al (16) has found that though modern medicine has helped to treat numerous diseases of human and animals yet the existing incurable diseases like diabetes, rheumatoid arthritis, acquired immunodeficiency syndrome (AIDS), cancer, side effect of allopathy medicines, increasing trends of antibiotics resistance and chemical and biopesticides causing dietary risk have made the condition more serious than ever before. So, now the scientists are to develop novel therapies. GA has shown minimum adverse reaction when compare to modern medicines GA has been proven to be the cost effective too.

GA showed curable effects against restoration of compromised renal function and renal calculi. Perhaps this reaction of GA was observed as it reduces excretion of calcium oxalate and inhibits process of crystallization. Experimental studies can be designed to its mechanism of action. (17)

The GA is one of the ingredients of 'Panchagawya' which is capable of treating many curable as well as incurable diseases. It has been used in Ayurvedic preparations since time immemorial as cited in ancient holy texts like Sushruta Samhita, CharakaSamhita, Vridhabhagabhatt, Bhavaprakash, RajniGhuntu, Atharva Veda, Amritasagar, etc. (7)

It has been found in studies that GA and distillate inhibited the free radicals by scavenging of Superoxide and DPPH radicals. Comparatively fresh GA was found to be more potent than its distillate. Both Fresh GA and its distillate have showed antimicrobial activity. The activity of Fresh Go Ark (FGA) was similar to that of Ofloxacin. (18)

In our study also we found that FGA was more effective than DGA when tested on human PBL in vitro.

\section{Conclusion}

We found the proliferative effect of GA on Human PBL, when compared to controls. FGA was found more potent to enhance cell viability $\%$ as compared to DGA. However both were competent to enhance the cell viability\%. It has been traditionally believed as an elixir of life since ancient time in India. We recommend the use of FGA on daily basis for great potency of normal cells and good health.

\section{Acknowledgement}

The authors are deeply grateful to Mr. Manish Tiwari, Asst. Prof., St. Aloysius' College (Autonomous) Jabalpur (M. P.) for providing the GA. We would also like to extend our profound gratitude to Principal, St. Aloysius' College (Autonomous) Jabalpur (M. P.) for providing necessary laboratory facilities and motivation for performing this research.

\section{References}

1. Jain NK, Gupta VB, Garg Rajesh, Silwat N. Efficacy of cow urine therapy on various cancer patients in Mandsaur district, India - a survey. International Journal of Green Pharmacy. 2010;1(4);29-35.

2. Mohanty I et al. Diversified Uses of Cow Urine. International Journal of Livestock Research 2014;6(3);20-22

3. Bhadauria H. Cow Urine- A Magical Therapy. Vishwa Ayurveda Parishad, 71-74. Int J Cow Sci 2002;1:32-6.

4. Chauhan RS, Singh BP, Singhal LK. Immunomodulation with Kamdhenu ark in mice. J ImmunolImmunopathol 2001;3:74-7.

5. Kumar S. Analysis of Cow's Urine for Detection of Lipase Activity and Anti-Microbial Properties. J Pharm BiolSci. 2013; 7(1); 01-08.

6. Bhavamishra, Bhavprakash - in Mutravarga / 4, Brahmashankar Mishra; Chaukhamba Sanskrit Sansthan, Varanasi, 9th ed. Vol.I, pp 778.

7. Pathak ML et al. Cow praising and importance of Panchyagavya as medicine. Sachitra Ayurveda. 2003; 5: 56-59.

8. Randhawa GK, Sharma R. Chemotherapeutic potential of cow urine: A review, Journal of Intercultural Ethnopharmacology, 2015;4(2) 180-186.

9. Randhawa GK. Cow urine distillate as bioenhancer. J Ayurveda Integr Med. 2010;1:240-241.

10. Chauhan RS, Singhal L. Harmful effects of Pesticides and their control through cowpathy. Int $\mathrm{J}$ Cow Sci 2006;2:61-70.].

11. Van MJ, Kaspers GJ, Cloos J. Cell sensitivity assays: the MTT assay. Methods Mol Biol. 2011;731:237-45

12. Gautam DS, Khanna A, Kumari N and Kumari R. An assessment of in vitro cytotoxicity of chlorpyrifos on normal human peripheral lymphocytes by MIT assay. World Journal of pharmacy and pharmaceutical sciences. 2016;5(8): 1116.1120

13. Mosmann T. Rapid colorimetric assay for cellular growth and survival: application to proliferation and cytotoxicity assays. J lmmun Methods, 1983; 65: 55-63.

14. Gulhane H, Nakanekar A, Mahakal N , Bhople S, Salunke A. Gomutra (Cow Urine): A 
Multidimensional Drug Review Article. Int. J. Res. Ayurveda Pharm. 8 (5), 2017:1-6.

15. Talokar OW et al. Clinical Evaluation of CowUrine Extract special reference to Arsha (Hemorrhoids). International Journal of Pharmaceutical Science Invention. 2013;2(3); 05-08.

16. Dhama K, Chakraborty S, Mahima, Yakoob WM. Novel and emerging therapies safeguarding health of human and their companion animals: A Review. Pak. J. Bio. Sci. 2013;16(3): 101-113.

17. Shukla AB, Mandavia DR, Barvaliya MJ, Baxi SN, Tripathi CB. Anti-Urolithiatic Effect of Cow Urine Ark on Ethylene Glycol-Induced Renal Calculi. Int Braz J Urol. 2013;39 (4): 565-571.

18. Jain, "The main elements of Cow- Urine \& their functions", http://www.cowurine.com (browsed on $3^{\text {rd }}$ September 2020. Time 6:54 PM). 